\title{
Reality on Parents' Awareness of Vocational Education for Students with Intellectual Disabilities in Vietnam
}

\author{
Thu-Giang Tran, Van-Hung Nguyen
}

\begin{abstract}
Vocational education for students with intellectual disabilities has been an issue that their parents pay much attention. Vocational education for students with intellectual disabilities is understood as the organization of activities to support students with intellectual disabilities to choose and develop the professional that best suits their abilities, needs and interests, and at the same time satisfy the human needs of the career fields. The data set on parents' awareness of vocational education for students with intellectual disabilities were collected directly through surveys in four provinces which are representatives of different regions in Vietnam. Parents participating in the survey are selected according to non-random sampling, combining between quota sampling and purposive sampling methods. Questionnaire address the criteria of skills, contents, methods, forms, needs and factors affecting vocational education based on parents' opinions. The data set has 144 valid records which are input, screened and analyzed. The data results reflect parents' responsiveness, so it is useful to develop activities of career-oriented guidance that considered the parents' expectation and opinions for their students with intellectual disabilities in educational institutions.
\end{abstract}

Keywords: intellectual disabilities, parents' perception, Vietnam, vocational education.

\section{INTRODUCTION}

Vocational education is essentially education on labor attitudes and proper sense of the profession; to familiarize students with some popular jobs in society and traditional local occupations. It is an activity to learn about the strengths and career trends of each student to encourage, guide and foster the most appropriate career skills. Career guidance is an educational activity made up of many different career-oriented activities. Each activity has its own goal, content and implementation. Vocational education results are synthesized the results of each career guidance activity and reflected in the career guidance capacity that students achieve after participating in career-oriented education (Fasching, 2014; Bartram \& Cavanagh, 2019). Vocational education is not only conducted in general schools but also in other educational institutions such as the Center for General-Career Technology; Continuing education centers; Vocational training centers,... Career-oriented education is not only conducted by staff, teachers and students in the school, but also conducted and supported by forces outside the school

Revised Manuscript Received on December 15, 2020.

* Correspondence Author

Thu-Giang Tran*, the Vietnam Institute of Educational Sciences, Vietnam. Email: giang.vnies@gmail.com

Van-Hung Nguyen, the Vietnam Institute of Educational Sciences, Vietnam. Email: hungvnies@gmail.com

(c) The Authors. Published by Blue Eyes Intelligence Engineering and Sciences Publication (BEIESP). This is an open access article under the CC BY-NC-ND license (http://creativecommons.org/licenses/by-nc-nd/4.0/) such as parents, social community, civil society organizations,... (Valaikiene, Kaffemaniene \& Baranauskiene, 2016). Students with intellectual disabilities participate in educational activities including career-oriented education at general schools or specialized educational institutions. However, with specific characteristics, the career-oriented education for students with intellectual disabilities also needs appropriate adjustments in order to bring about practical effects. Vocational education for students with intellectual disabilities is understood as the organization of activities to support students with intellectual disabilities to choose and develop the professional that best suits their abilities, needs and interests, and at the same time satisfy the human needs of the career fields (Nguyen, 2020). Vocational education for students with intellectual disabilities contributes to their confidence, integration with the community, communication skills psycho-physiology development in accordance with abilities and needs. Students after graduating from school have the ability to be partially independent, take care of themselves, protect themselves in everyday situations. In addition, vocational education discovers the strengths of each student for career guidance and vocational training, followed by connecting with job opportunities so that students with intellectual disabilities have income to pay for a part of their own needs, reducing the burden on families (Fasching, 2014; Hart Barnett \& Crippen, 2014; Pristiwaluyo, 2017). For parents of students with intellectual disabilities, vocational education helps parents to orient to handle situations when their children are in puberty; to motivate and set goals, implement long-term goals in children; to set determination and energy to overcome difficulties, share experiences when raising children; to create a safe environment for children to participate in learning career skills and career orientation in future (ILO, 2016; Nguyen, 2020).

\section{SURVEY METHOD AND SAMPLE}

Data was collected through direct questionnaire surveys at locality. Information of interest in the questionnaire was the parents' awareness about issues related to vocational education for their students with intellectual disabilities: skills, programs, contents, methods, forms, supports, information, affected factors. Survey used a non-random sampling method which was combined between purposive sampling and quota sampling. Based on practical resources and conditions, the study surveyed 144 parents of students with intellectual disabilities.

Published By:

Blue Eyes Intelligence Engineering \& Sciences Publication

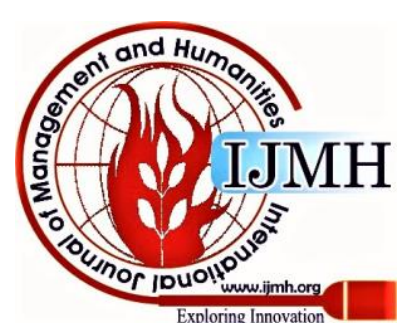




\section{Reality on Parents' Awareness of Vocational Education for Students with Intellectual Disabilities in Vietnam}

4 localities in Vietnam with economic conditions in each region were selected: Hanoi and Hai Duong represents the North; Nghe An represents the Central; Ho Chi Minh city represents the South. For each selected province, randomly select one city/ district/ town that represents the metropolitan area, and randomly select one district to represent the rural area. The survey was conducted in September and October 2020. Information of parents responding to the survey is entered and screened. No records have been removed due to missing values. The data set used for analysis has a total of 144 valid records.

\section{SURVEY DATA}

The survey data provides information about respondents including gender, age range, the highest degree, employment status, household status and current residence (see Table 1).

Table 1. Respondents' characteristics

\begin{tabular}{|l|c|c|}
\hline Characteristics & $\mathbf{N}$ & $\mathbf{\%}$ \\
\hline Gender & $\mathbf{1 4 4}$ & $\mathbf{1 0 0 . 0 0}$ \\
\hline Male & 45 & 31.25 \\
\hline Female & 99 & 68.75 \\
\hline Age & $\mathbf{1 4 4}$ & $\mathbf{1 0 0 . 0 0}$ \\
\hline Under 30 & 4 & 2.78 \\
\hline Under 40 & 120 & 83.33 \\
\hline Others & 20 & 13.89 \\
\hline The highest degree & $\mathbf{1 4 4}$ & $\mathbf{1 0 0 . 0 0}$ \\
\hline Under upper secondary & 48 & 33.33 \\
\hline Upper secondary & 20 & 13.89 \\
\hline Technical secondary & 24 & 16.67 \\
\hline College, university & 48 & 33.33 \\
\hline Post graduate & 4 & 2.78 \\
\hline Employment status & $\mathbf{1 4 4}$ & $\mathbf{1 0 0 . 0 0}$ \\
\hline Unemployment & 13 & 9.03 \\
\hline Unstable employment & 104 & 72.22 \\
\hline Stable employment & 27 & 18.75 \\
\hline $\begin{array}{l}\text { Household } \\
\text { (certified) }\end{array}$ & $\mathbf{1 4 4}$ & $\mathbf{1 0 0 . 0 0}$ \\
\hline Poor & & \\
\hline Near poor & 17 & 11.81 \\
\hline Normal & 48 & 33.33 \\
\hline Provinces & 79 & 54.86 \\
\hline Hanoi & $\mathbf{1 4 4}$ & $\mathbf{1 0 0 . 0 0}$ \\
\hline Hai Duong & 36 & 25.00 \\
\hline Nghe An & 36 & 25.00 \\
\hline Ho Chi Minh city & 48 & 16.67 \\
\hline & & 33.33 \\
\hline & 24 & \\
\hline & & \\
\hline
\end{tabular}

Table 2 displays the assessment of parents of students with intellectual disabilities related skills to attend vocational education. There were six groups of skills and respondents valuated the priority from 1 to 6 with No. 1 as the most priority.

Table 2. Parents' assessment about skills of students with intellectual disabilities to attend vocational education

\begin{tabular}{|c|l|c|c|}
\hline No. & \multicolumn{1}{|c|}{ Content } & Mean & Rank \\
\hline 1 & Motor skills & 3.25 & 2 \\
\hline 2 & Language use skills & 3.73 & 4 \\
\hline 3 & Self-help skills & 2.04 & 1 \\
\hline 4 & Social skills skills & 4.63 & 6 \\
\hline 5 & $\begin{array}{l}\text { Self-management } \\
\text { (behavior, time, emotion) }\end{array}$ & 3 \\
\hline 6 & $\begin{array}{l}\text { Cognition skills (reading, } \\
\text { writing, maths) }\end{array}$ & 4.04 & 5 \\
\hline
\end{tabular}

From table 3 to table 7, the data on parents' opinions of contents, methods, forms, information and information resources about vocational education for students with intellectual disabilities. At table 3, there were nine items of vocational education contents and respondents evaluated the priority from 1 to 9 with No. 1 as the most priority. The tables from 4 to 7 presents items that the answers were multiple-choice.

Table 3. Parents' opinions about vocational education contents for students with intellectual disabilities

\begin{tabular}{|c|l|c|c|}
\hline No. & \multicolumn{1}{|c|}{ Content } & Mean & Rank \\
\hline 1 & $\begin{array}{l}\text { Educating students to realize } \\
\text { several careers of parents, } \\
\text { relatives }\end{array}$ & 2.81 & 2 \\
\hline 2 & $\begin{array}{l}\text { Educating students to realize } \\
\text { several local traditional careers }\end{array}$ & 5.06 & 4 \\
\hline 3 & $\begin{array}{l}\text { Educating students to realize } \\
\text { several basic careers }\end{array}$ & 5.30 & 6 \\
\hline 4 & $\begin{array}{l}\text { Guiding students to attend daily } \\
\text { work at home }\end{array}$ & 2.70 & 1 \\
\hline 5 & $\begin{array}{l}\text { Guiding students to attend daily } \\
\text { work at school }\end{array}$ & 3.91 & 3 \\
\hline 6 & $\begin{array}{l}\text { Practicing students with } \\
\text { self-management skills }\end{array}$ & 5.55 & 8 \\
\hline 7 & $\begin{array}{l}\text { Practicing students with social } \\
\text { skills }\end{array}$ & 5.19 & 5 \\
\hline 8 & $\begin{array}{l}\text { Identifying students' strengths } \\
\text { and talents }\end{array}$ & 5.51 & 7 \\
\hline 9 & $\begin{array}{l}\text { Identifying students hobbies } \\
\text { related vocational education }\end{array}$ & 2.81 & 2 \\
\hline
\end{tabular}

Table 4. Parents' opinions about vocational education methods for students with intellectual disabilities

\begin{tabular}{|c|l|c|c|}
\hline No. & \multicolumn{1}{|c|}{ Methods } & Number & Rank \\
\hline 1 & Explanation & 84 & 2 \\
\hline 2 & Practical observation & 80 & 3 \\
\hline 3 & $\begin{array}{l}\text { Illustration with video, } \\
\text { pictures }\end{array}$ & 85 & 1 \\
\hline 4 & Project & 30 & 6 \\
\hline 5 & Group discussion & 72 & 4 \\
\hline 6 & Role-play & 60 & 5 \\
\hline 7 & Problem solving & 60 & 5 \\
\hline
\end{tabular}

Table 5. Parents' opinions about vocational education forms for students with intellectual disabilities

\begin{tabular}{|c|l|c|c|}
\hline No. & \multicolumn{1}{|c|}{ Forms } & Number & Rank \\
\hline 1 & $\begin{array}{l}\text { Gathering at vocational } \\
\text { education institutions }\end{array}$ & 75 & 1 \\
\hline 2 & $\begin{array}{l}\text { Following individuals } \\
\text { Cooperating with vocational } \\
\text { education institutions with }\end{array}$ & 57 & 3 \\
\hline 4 & $\begin{array}{l}\text { Cooperating with } \\
\text { enterprises }\end{array}$ & $\begin{array}{l}\text { Cooperating } \\
\text { organization of/ for people } \\
\text { with disabilities }\end{array}$ & 5 \\
\hline
\end{tabular}

Blue Eyes Intelligence Engineering \& Sciences Publication

(C) Copyright: All rights reserved.

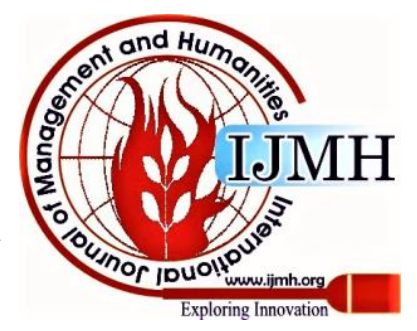


Table 6. Parents' opinions about information on vocational education for students with intellectual disabilities

\begin{tabular}{|c|l|c|c|}
\hline No. & \multicolumn{1}{|c|}{ Info } & Number & Rank \\
\hline 1 & $\begin{array}{l}\text { Models of vocational education } \\
\text { for students with intellectual } \\
\text { disabilities }\end{array}$ & 44 \\
\hline 2 & $\begin{array}{l}\text { Programs of vocational } \\
\text { education for students with } \\
\text { intellectual disabilities }\end{array}$ & 108 & 1 \\
\hline 3 & $\begin{array}{l}\text { Capacity of students with } \\
\text { intellectual disabilities attending } \\
\text { vocational education }\end{array}$ & $\begin{array}{l}\text { Methods of vocational education } \\
\text { for students with intellectual } \\
\text { disabilities }\end{array}$ & 45 \\
\hline 5 & $\begin{array}{l}\text { Appropriate careers for students } \\
\text { with intellectual disabilities }\end{array}$ & 78 & 2 \\
\hline
\end{tabular}

Table 7. Parents' opinions about information resources on vocational education for students with intellectual disabilities

\begin{tabular}{|c|l|c|c|}
\hline No. & \multicolumn{1}{|c|}{ Info resources } & Number & Rank \\
\hline 1 & Via the Internet & 98 & 2 \\
\hline 2 & $\begin{array}{l}\text { Local programs of } \\
\text { vocational education }\end{array}$ & 70 & 4 \\
\hline 3 & From other parents & 64 & 5 \\
\hline 4 & $\begin{array}{l}\text { From magazines, } \\
\text { newspapers }\end{array}$ & 80 & 3 \\
\hline 5 & $\begin{array}{l}\text { From teachers, } \\
\text { schools }\end{array}$ & 121 & 1 \\
\hline
\end{tabular}

Fig 1. Parents' needs of supports in vocational education for their children with intellectual disabilities

Figure 1 illustrated the supports that parents need in vocational education for students with intellectual disabilities. The 4-level scale is used from level 1: very necessary, level 2: necessary, level 3: less necessary to level 4: none necessary.

Table 8, 9 and 10 listed limitations, factors and suggestions towards vocational education for intellectual disabilities. For each question, respondents can choose different items.

Table 8. Parents' opinions about key limitations of students with intellectual disabilities to access vocational education

\begin{tabular}{|c|l|c|c|}
\hline No. & \multicolumn{1}{|c|}{ Info resources } & Number & Rank \\
\hline 1 & $\begin{array}{l}\text { Gaps between knowledge, skills } \\
\text { and practical career } \\
\text { requirements }\end{array}$ & 28 & 4 \\
\hline 2 & $\begin{array}{l}\text { Lack of vocational education } \\
\text { institutions for students with } \\
\text { intellectual disabilities }\end{array}$ & 70 & 5 \\
\hline 3 & $\begin{array}{l}\text { Expensive training fund education } \\
\text { Vocational meeting } \\
\text { institutions not nosing } \\
\text { families' needs }\end{array}$ & 121 & 1 \\
\hline 5 & $\begin{array}{l}\text { Difficulties in choosing } \\
\text { appropriate careers for students } \\
\text { with intellectual disabilities }\end{array}$ & \\
\hline
\end{tabular}

Table 9. Parents' opinions of factors affecting vocational education results

\begin{tabular}{|c|l|c|c|}
\hline No. & \multicolumn{1}{|c|}{ Contents } & Number & Rank \\
\hline 1 & $\begin{array}{l}\text { Having capacity meeting the } \\
\text { needs of vocational education }\end{array}$ & 20 & 3 \\
\hline 2 & $\begin{array}{l}\text { Having good families' } \\
\text { awareness, expectation, } \\
\text { economic and cooperation } \\
\text { with educational institutions }\end{array}$ & 21 & 2 \\
\hline 3 & $\begin{array}{l}\text { Educational institutions } \\
\text { having good issues of human } \\
\text { resource, program, forces } \\
\text { collaboration }\end{array}$ & $\begin{array}{l}\text { Society meeting the } \\
\text { conditions of vocational } \\
\text { education }\end{array}$ & 12 \\
\hline 5 & $\begin{array}{l}\text { Locality having professional } \\
\text { strengths }\end{array}$ & 12 & 5 \\
\hline 6 & $\begin{array}{l}\text { Having favorable vocational } \\
\text { education policy }\end{array}$ & 24 & 1 \\
\hline
\end{tabular}

Published By:

Blue Eyes Intelligence Engineering \& Sciences Publication

(C) Copyright: All rights reserved.

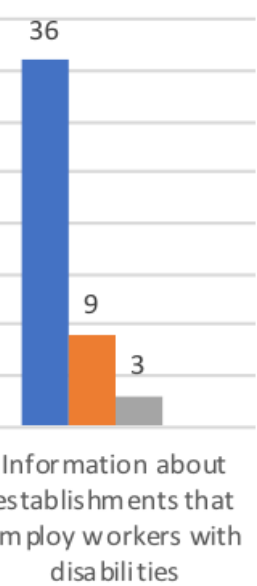

disabilities 


\section{Reality on Parents' Awareness of Vocational Education for Students with Intellectual Disabilities in Vietnam}

Table 10. Suggestions of parents to improve the quality of vocational education for students with intellectual disabilities

\begin{tabular}{|c|c|c|c|}
\hline No. & Contents & Number & Rank \\
\hline 1 & $\begin{array}{l}\text { Building a legal corridor on } \\
\text { vocational education for } \\
\text { students with intellectual } \\
\text { disabilities }\end{array}$ & 23 & 4 \\
\hline 2 & $\begin{array}{l}\text { Integrating vocational } \\
\text { education into educational } \\
\text { programs for students with } \\
\text { intellectual disabilities }\end{array}$ & 34 & 2 \\
\hline 3 & $\begin{array}{l}\text { Coordinating with vocational } \\
\text { training institutions and } \\
\text { cooperating with employers to } \\
\text { provide vocational education } \\
\text { for students with intellectual } \\
\text { disabilities }\end{array}$ & 38 & 1 \\
\hline 4 & $\begin{array}{l}\text { Family-based vocational } \\
\text { education for students with } \\
\text { intellectual disabilities }\end{array}$ & 19 & 5 \\
\hline 5 & $\begin{array}{l}\text { Community-based vocational } \\
\text { education for students with } \\
\text { intellectual disabilities }\end{array}$ & 32 & 3 \\
\hline
\end{tabular}

\section{CONCLUSION}

The data set includes information about parents' awareness of vocational education for students with intellectual disabilities. The data set is available for continuing research orientation. This can help the educators and administrators to develop and implement the vocational education programs appropriate to parents' expectation. Additionally, this data set is very useful in the studies of school activities for students with intellectual disabilities.

\section{REFERENCES}

1. Bartram, T., \& Cavanagh, J. (2019). Re-thinking vocational education and training: creating opportunities for workers with disability in open employment. Journal of Vocational Education \& Training, 71(3), 339-349.

2. Fasching, H. (2014). Vocational education and training and transitions into the labour market of persons with intellectual disabilities. European Journal of special needs education, 29(4), 505-520.

3. Hart Barnett, J. E., \& Crippen, R. (2014). Eight Steps to School-Based Employment Training for Adolescents with Autism Spectrum Disorder and Intellectual Disability. Physical Disabilities: Education and Related Services, 33(2), 1-15.

4. International Labour Organization, Including persons with disabilities in technical and vocational education and training, retrieved from https://www.ilo.org/wcmsp5/groups/public/---asia/---ro-bangkok/---il o-dhaka/documents/publication/wcms_543304.pdf

5. Nguyen, V.H. (coordinator). (2020). Model of vocational education for people with intellectual disabilities and autism spectrum disorders in Vietnam, Ministerial project, Ministry of Education and Training, Vietnam.

6. Pristiwaluyo, T. (2017). Developing Vocational Skills for Children of Intellectual Disabilities. In 9th International Conference for Science Educators and Teachers (ICSET 2017). Atlantis Press.

7. Valaikiene, A., Kaffemaniene, I., \& Baranauskiene, I. (2016). The structure and guidelines of pre-vocational education and assistance for pupils with mild intellectual disabilities. In Proceedings of the International Scientific Conference, Volume III (Vol. 201, p. 211).

\section{AUTHORS PROFILE}

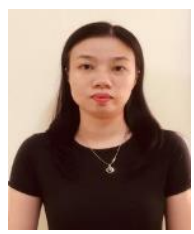

Ms. Thu-Giang Tran, has been working as a researcher at the Vietnam National Institute of Educational Sciences for 14 years. Her major research focuses on Education and Special Education. She got the Master of Education in 2012.

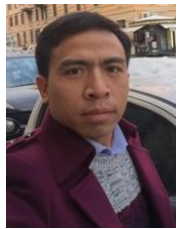

Mr. Van-Hung Nguyen, PHD is the Head of Special Education Service Division of the Center for National Special Education, the Vietnam Institute of Educational Sciences. He successfully defended his doctoral thesis in September, 2017. He has been researching in the field of special education over 15 years. The group of children with disabilities that he focuses on research and teaching is children with developmental disorders, specially children with intellectual disabilities.

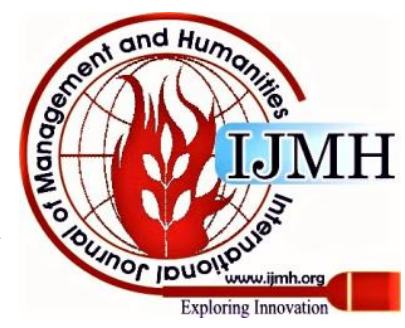

